\title{
Dry Deposition Velocity Estimation for the Savannah River Site: Part 1 - Parametric Analysis
}

\author{
BA Napier
}

Reviewed by: JP Rishel

January 2012

\section{Pacific Northwest}

NATIONAL LABORATORY

Proudly Operated by Battelle Since 1965 


\title{
DISCLAIMER
}

This report was prepared as an account of work sponsored by an agency of the United States Government. Neither the United States Government nor any agency thereof, nor Battelle Memorial Institute, nor any of their employees, makes any warranty, express or implied, or assumes any legal liability or responsibility for the accuracy, completeness, or usefulness of any information, apparatus, product, or process disclosed, or represents that its use would not infringe privately owned rights. Reference herein to any specific commercial product, process, or service by trade name, trademark, manufacturer, or otherwise does not necessarily constitute or imply its endorsement, recommendation, or favoring by the United States Government or any agency thereof, or Battelle Memorial Institute. The views and opinions of authors expressed herein do not necessarily state or reflect those of the United States Government or any agency thereof.

\author{
PACIFIC NORTHWEST NATIONAL LABORATORY \\ operated by \\ BATTELLE \\ for the \\ UNITED STATES DEPARTMENT OF ENERGY \\ under Contract DE-AC05-76RL01830
}

Printed in the United States of America
Available to DOE and DOE contractors from the Office of Scientific and Technical Information,
P.O. Box 62, Oak Ridge, TN 37831-0062;
ph: (865) 576-8401
fax: $(865) 576-5728$
email: reports@adonis.osti.gov
Available to the public from the National Technical Information Service
5301 Shawnee Rd., Alexandria, VA 22312 ph: (800) 553-NTIS (6847)
email: orders@ntis.gov <http://www.ntis.gov/about/form.aspx>
Online ordering: http://www.ntis.gov

This document was printed on recycled paper. 


\title{
Dry Deposition Velocity Estimation for the Savannah River Site: Part 1 - Parametric Analysis
}

\author{
BA Napier
}

January 2012

Prepared for

the U.S. Department of Energy

under Contract DE-AC05-76RL01830

Pacific Northwest National Laboratory

Richland, Washington 99352 



\section{Summary}

Values for the dry deposition velocity of airborne particles were estimated with the GENII Version 2.10 computer code for the Savannah River site using assumptions about surface roughness parameters and particle size and density. Use of the GENII code is recommended by the U.S. Department of Energy for this purpose. Meteorological conditions evaluated include atmospheric stability classes D, E, and F and wind speeds of $0.5,1.0,1.5$, and $3.0 \mathrm{~m} / \mathrm{s}$. Local surface roughness values ranging from 0.03 to 2 meters were evaluated. Particles with mass mean diameters of 1, 5, and 10 microns and densities of 1, 3, and $5 \mathrm{~g} / \mathrm{cm}^{3}$ were evaluated. 



\section{Acronyms and Abbreviations}

$\begin{array}{ll}\mu \mathrm{m} & \text { micrometer } \\ \text { AMAD } & \text { Activity Median Aerodynamic Diameter } \\ \mathrm{cm} & \text { centimeter } \\ \mathrm{cm} / \mathrm{s} & \text { centimer/second } \\ \text { DOE } & \text { U.S. Department of Energy } \\ \text { DV } & \text { deposition velocity (as used in certain referenced DOE documents) } \\ \text { EPA } & \text { U.S. Environmental Protection Agency } \\ \text { GENII2 } & \text { Generalized Environmental Radiation Dosimetry Software System Hanford Dosimetry } \\ & \text { System, Version 2 } \\ \text { ISC3 } & \text { Industrial Source Complex } \\ \text { MACCS2 } & \text { Methods for Estimation of Leakages and Consequences of Releases Accident } \\ & \text { Consequence Code System, Version 2 } \\ \text { M-O } & \text { Monin-Obukhov } \\ \text { m } & \text { meter } \\ \text { m/s } & \text { meter/second } \\ \text { SRS } & \text { Savannah River Site }\end{array}$





\section{Contents}

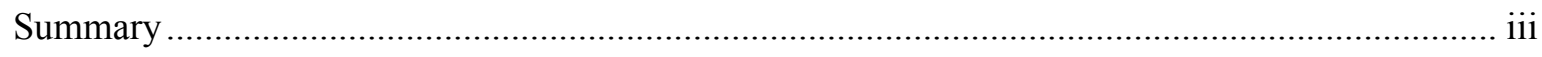

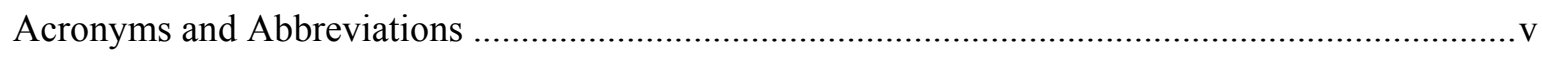

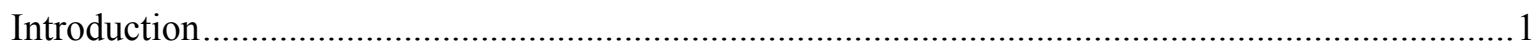

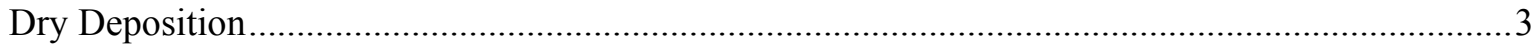

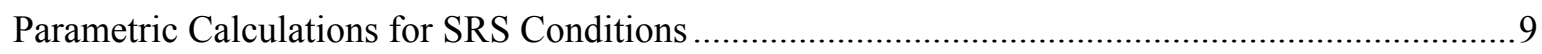

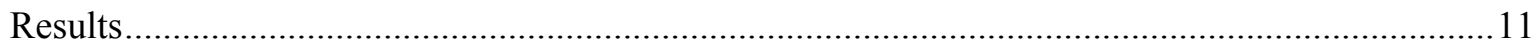

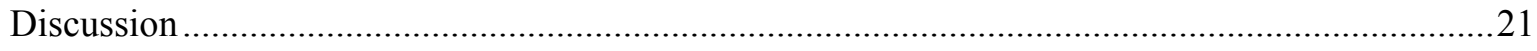

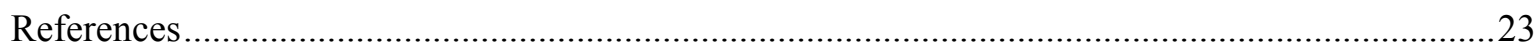




\section{Figures}

Figure 1 Relationship between Stability Class and M-O Length as a Function of Surface Roughness Length (Golder 1972)........................................... 5

Figure 2 Variation of Dry DV as a Function of Wind Speed, Stability Class, and Particle Density; Developed for $1 \mu \mathrm{m}$ Particles and a Surface Roughness of $0.03 \mathrm{~m}$.

Figure 3 Variation of Dry DV as a Function of Wind Speed, Stability Class, and Particle Density; Developed for $10 \mu \mathrm{m}$ particles and a Surface Roughness of $0.03 \mathrm{~m}$.

Figure 4 Variation of Dry DV as a Function of Wind Speed, Stability Class, and Particle Density; Developed for $1 \mu \mathrm{m}$ Particles and a Surface Roughness of $1 \mathrm{~m}$. 16

Figure 5 Variation of Dry DV as a Function of Wind Speed, Stability Class, and Particle Density; Developed for $10 \mu \mathrm{m}$ particles and a Surface Roughness of $1 \mathrm{~m}$.

Figure 6 Variation of Dry DV as a Function of Surface Roughness; Developed for Particles of Density $1 \mathrm{~g} / \mathrm{cm}^{3}$, Stability Class D.

Figure 7 Variation of Dry DV as a Function of Surface Roughness; Developed for Particles of Density $5 \mathrm{~g} / \mathrm{cm}^{3}$, Stability Class D.

Figure 8 Variation of Dry DV as a Function of Surface Roughness; Developed for Particles of Density $1 \mathrm{~g} / \mathrm{cm}^{3}$, Stability Class F.

Figure 9 Variation of Dry DV as a Function of Surface Roughness; Developed for Particles of Density $5 \mathrm{~g} / \mathrm{cm}^{3}$, Stability Class F.

Figure $10 \mathrm{DV}$ as a function of particle mass (volume*density) for various wind speed/stability combinations

\section{Tables}

Table 1. Settling velocities of particles of various diameter and density, estimated for stability class $\mathrm{D}$ and $3 \mathrm{~cm}$ surface roughness

Table 2. Dry DV evaluated as a function of particle diameter, particle density, surface roughness, wind speed, and atmospheric stability class. 


\section{Introduction}

Concerns were raised by the Defense Nuclear Facilities Safety Board regarding the default values of deposition velocity (DV) used in the Methods for Estimation of Leakages and Consequences of Releases Accident Consequence Code System, Version 2 (MACCS2) computer code. The U.S. Department of Energy (DOE) concluded that the MACCS2 default values of $0.01 \mathrm{~m} / \mathrm{s}$ for unfiltered/unmitigated releases and $0.001 \mathrm{~m} / \mathrm{s}$ for filtered/mitigated releases are not reasonably conservative for all DOE sites and accident scenarios. Until DOE formally revises the MACCS2 Computer Code Application Guidance for Documented Safety Analysis Final Report (DOE 2004) to address this issue, DOE recommends the following if using the MACCS2 computer code to develop conservative results for accident dose consequence calculations:

1. Calculate site-specific DV values for unmitigated/unfiltered and mitigated/filtered particulate releases; or

2. Use default DV values of $0.001 \mathrm{~m} / \mathrm{s}$ for unmitigated/unfiltered particulate releases and $0.0001 \mathrm{~m} / \mathrm{s}$ for mitigated/filtered particulate release; or

3. Use a more sophisticated computer code than MACCS2 to determine the 95 th percentile dose at the site boundary.

DOE Safety Bulletin No. 2011-02 (DOE 2011) recommends "While a number of variations in the resistance models are available, the methodology used in the Generalized Environmental Radiation Dosimetry Software System Hanford Dosimetry System, Version 2 (GENII2) code allows for the incorporation of site-specific parameters without an extensive independent modeling effort. In addition, the Office of Health, Safety and Security's recommendation to use a model like GENII2 for unmitigated/unfiltered releases is based on the model's ability to accurately assess the minimum DV found at low wind speeds and smooth surface conditions, while simultaneously being able to predict variations in DV consistent with observed and theoretical patterns that arise from changes in surface roughness and light wind speeds. Given the light winds typically associated with the meteorology that results in the $95^{\text {th }}$ percentile impact, the selected model needs to perform well in these conditions. Further, because the input value for surface roughness significantly affects the results from site to site, a model that can account for variations in surface roughness is also needed. Moreover, the U.S. Environmental Protection Agency (EPA) approved the use of GENII2 for calculating radiation dose and risk from radionuclides released to the environment. If sites choose to use the GENII2 model, a calculated site-specific value for DV for particulates can then be used as input for the MACCS2 computer code, replacing the default recommended value of $0.1 \mathrm{~cm} / \mathrm{s} . "$

The GENII Version 2.10 computer package (Napier et al. 2010) has been used to estimate dry DV for the Savannah River Site (SRS) as described below. The calculations were prepared in the manner required in the GENII Software Quality Assurance manual (PNNL 2009) and an application package prepared and reviewed. A spreadsheet implementation of the equations described below was used to verify the results, as required by PNNL under Subject Area Safety Software, Exhibit: Utility Calculation Guidance (https://hdi-sa.pnl.gov/standard/6e/6e09e010.htm, effective date March 2007).

PNNL developed GENII under quality assurance (QA) plans based on the American National Standards Institute (ANSI) standard NQA-1 as implemented in the Lab's Quality Assurance Manual. GENII has its own PNNL GENII Software Quality Assurance Manual (PNNL 2009) which defines code 
development, maintenance, and usage requirements. All code development steps have been documented and tested, and hand calculations have verified the code's implementation of major transport and exposure pathways for a subset of the radionuclide library. A collection of hand calculations and other verification activities is available.

The DOE Office of Quality Assurance, within the Office of Health, Safety, and Security, has completed an evaluation of GENII Version 2.10 for inclusion in the DOE safety software Central Registry (the DOE "toolbox") (DOE 2012). The DOE evaluation identified 5 recommendations to complete meeting of the DOE quality assurance requirements and criteria in DOE Order (O) 414.1C, Quality Assurance, and DOE Guide 414.1-4, Safety Software Guide for Use with 10 CFR 830, Subpart A, Quality Assurance Requirements, and DOE O 414.1C, Quality Assurance. The author of this report is in the final stages of applying the five recommendations and GENII Version 2.10 (probably identified as Version 2.10.1 to meet one of the recommendations) will soon be available to all users through the DOE toolbox. 


\section{Dry Deposition}

The flux of material to the ground resulting from dry deposition is assumed to be proportional to the material's concentration in the air near the ground. Deposition velocity is the term given to the constant of proportionality. Thus,

$$
\omega_{\mathrm{ij}}(\mathrm{t})=\mathrm{V}_{\mathrm{dd}} \chi_{\mathrm{ij}}(1, \mathrm{t})
$$

where $\quad \omega_{\mathrm{ij}}(\mathrm{t})=$ the dry deposition rate at position $\mathrm{i}, \mathrm{j}$ at time $\mathrm{t}$

$\mathrm{v}_{\mathrm{dd}}=$ the dry deposition velocity, DV

$\chi_{\mathrm{ij}}(1, \mathrm{t})=$ the concentration at a height of $1 \mathrm{~m}$ at position $\mathrm{i}, \mathrm{j}$ at time $\mathrm{t}$.

It is important to note that the DV is a function of the height at which the concentration is measured or calculated. A reference height of $1 \mathrm{~m}$ is assumed for deposition velocities in the GENII atmospheric models.

Dry deposition velocities have been calculated from experimental data for particles and gases. In general, the deposition velocities observed for any particular material have a wide range of values. The dry DV may be modeled using an analogy to electrical resistance. Resistances are associated with atmospheric conditions, physical and chemical characteristics of the material, and the physical, chemical and biological properties of the surface. Seinfeld (1986) describes the resistance analogy.

For small particles and gases the resistance model for dry deposition velocities is

$$
\mathrm{V}_{\mathrm{dd}}=\left(\mathrm{r}_{\mathrm{a}}+\mathrm{r}_{\mathrm{s}}+\mathrm{r}_{\mathrm{t}}+\mathrm{r}_{\mathrm{a}} \mathrm{r}_{\mathrm{s}} \mathrm{v}_{\mathrm{s}}\right)^{-1}+\mathrm{v}_{\mathrm{s}}
$$

where $\quad r_{a}=$ aerodynamic resistance $(\mathrm{s} / \mathrm{m})$

$\mathrm{r}_{\mathrm{s}}=$ surface resistance $(\mathrm{s} / \mathrm{m})$

$\mathrm{r}_{\mathrm{t}}=$ transfer resistance $(\mathrm{s} / \mathrm{m})$

$\mathrm{v}_{\mathrm{s}}=$ the gravitational settling velocity; a function of particle size and density.

The aerodynamic and surface resistances are generally calculated from near surface wind data. In contrast, the transfer resistance is generally a function of the depositing surface.

The aerodynamic resistance is calculated directly from the wind speed and a parameter that is characteristic of the turbulence in the lowest layer of the atmosphere. The usual parameterization for the aerodynamic resistance is

$$
\mathrm{r}_{\mathrm{a}}=\mathrm{U}(\mathrm{z}) / \mathrm{u}^{2}
$$


where $\quad \mathrm{z}=$ the height at which the concentration is estimated

$\mathrm{u}_{*}=$ the characteristic turbulence velocity, called the friction velocity.

$\mathrm{U}(\mathrm{z})=$ wind speed at height $\mathrm{z}$

The concentration is approximately constant for $\mathrm{z}<0.2 \sigma_{\mathrm{z}}$ as long as $\mathrm{x}$ is sufficiently large that $\sigma_{\mathrm{z}}$ is greater than or equal to the height of release. Thus, for most elevated release cases, the $10 \mathrm{~m}$ wind speed may be used directly in calculating $r_{\mathrm{a}}$.

The "friction velocity" is derived from the atmospheric boundary layer similarity theory proposed by Monin and Obukhov (1954). The basic hypothesis of the similarity theory is that a number of parameters in the atmospheric layer near the ground, including the wind profiles, should be universal functions of the friction velocity, a length scale, and the height above ground. The length scale, $\mathrm{L}$, is referred to as the Monin-Obukhov (M-O) length and the ratio $\mathrm{z} / \mathrm{L}$ is related to atmospheric stability. The $\mathrm{M}-\mathrm{O}$ length is a measure of atmospheric stability. It varies from small negative values (a few meters) in extremely unstable atmospheric conditions to negative infinity as the atmospheric stability approaches neutral from unstable. In extremely stable conditions, the M-O length is small and positive. As neutral conditions are approached from stable conditions, the M-O length approaches infinity. Thus, there is a discontinuity in the M-O length at neutral. However, this discontinuity is not a problem because the M-O length is found in the denominator of expressions. When $z / L$ is negative and large (e.g., $<-2)$, the atmosphere is extremely unstable (convective). When $\mathrm{z} / \mathrm{L}$ is near zero, the atmosphere is neutral, and when it is positive and large (e.g., > 1), the atmosphere is extremely stable. A large body of experimental data supports the M-O similarity theory.

The diabatic wind profile is

$$
\mathrm{U}(\mathrm{z})=\frac{\mathrm{u} *}{\mathrm{k}}\left[\ln \left(\frac{\mathrm{z}}{\mathrm{Z}_{0}}\right)-\psi\left(\frac{\mathrm{z}}{\mathrm{L}}\right)\right]
$$

where $\quad \mathrm{U}(\mathrm{z})=$ wind speed at height $\mathrm{z}(\mathrm{m} / \mathrm{s})$

$\mathrm{u}_{*}=$ friction velocity (boundary-layer turbulence scaling velocity) $(\mathrm{m} / \mathrm{s})$

$\mathrm{k}=$ von Karman constant, which has a value of about 0.4 (no units)

$\mathrm{z}=$ height $(\mathrm{m})$

$\mathrm{z}_{0}=$ measure of local surface roughness (roughness length) $(\mathrm{m})$

$\psi=$ stability correction factor

$\mathrm{L}=\mathrm{M}-\mathrm{O}$ length $(\mathrm{m})$

The term $\psi(z / L)$ accounts for the effects of stability on the wind profile. In stable atmospheric conditions, $\psi(\mathrm{z} / \mathrm{L})$ has the form $-\alpha \mathrm{z} / \mathrm{L}$, where $\alpha$ is a value between 4.7 and 5.2. For the GENII models, a value of 5 is used for $\alpha$. In neutral conditions $\psi(\mathrm{z} / \mathrm{L})$ is zero, and the diabatic profile simplifies to a logarithmic profile.

In unstable air, $\psi(\mathrm{z} / \mathrm{L})$ is more complicated. According to Panfosky and Dutton (1984), the most common form of $\psi(\mathrm{z} / \mathrm{L})$ for unstable conditions is based on the work by Businger et al. (1971) and Paulson (1970). It is

$$
\psi\left(\frac{\mathrm{z}}{\mathrm{L}}\right)=\ln \left(\left[\frac{1+\mathrm{x}^{2}}{2}\right]\left[\frac{1+\mathrm{x}}{2}\right]^{2}\right)-2 \tan ^{-1} \mathrm{x}+\frac{\pi}{2}
$$


where

$$
\mathrm{x}=(1-16 \mathrm{z} / \mathrm{L})^{1 / 4}
$$

Equation (4) is used to estimate the friction velocity $\left(\mathrm{u}_{*}\right)$ from wind speed, surface roughness, and the M-O length.

Golder (1972) provides a means for converting from stability class estimates to M-O lengths. Figure 1, derived from Golder (1972, Figure 5), shows the range for $1 / \mathrm{L}$ as a function of stability classes and surface roughness. Mid-range values for $1 / \mathrm{L}$ from this figure are used by the model to estimate $1 / \mathrm{L}$.

The surface resistance is only a function of the friction velocity. It is

$$
\mathrm{r}_{\mathrm{s}}=2.6 /(0.4 \mathrm{u} *)=6.5 / \mathrm{u} *
$$

where $\quad 2.6=$ a dimensionless empirical constant and 0.4 is von Karman's constant.

A gravitational settling term is needed for larger particles where the settling velocity is not negligible. The settling velocity used in the GENII codes is the same as that for the EPA Industrial Source Complex (ISC3) model (EPA 1995) and is given by

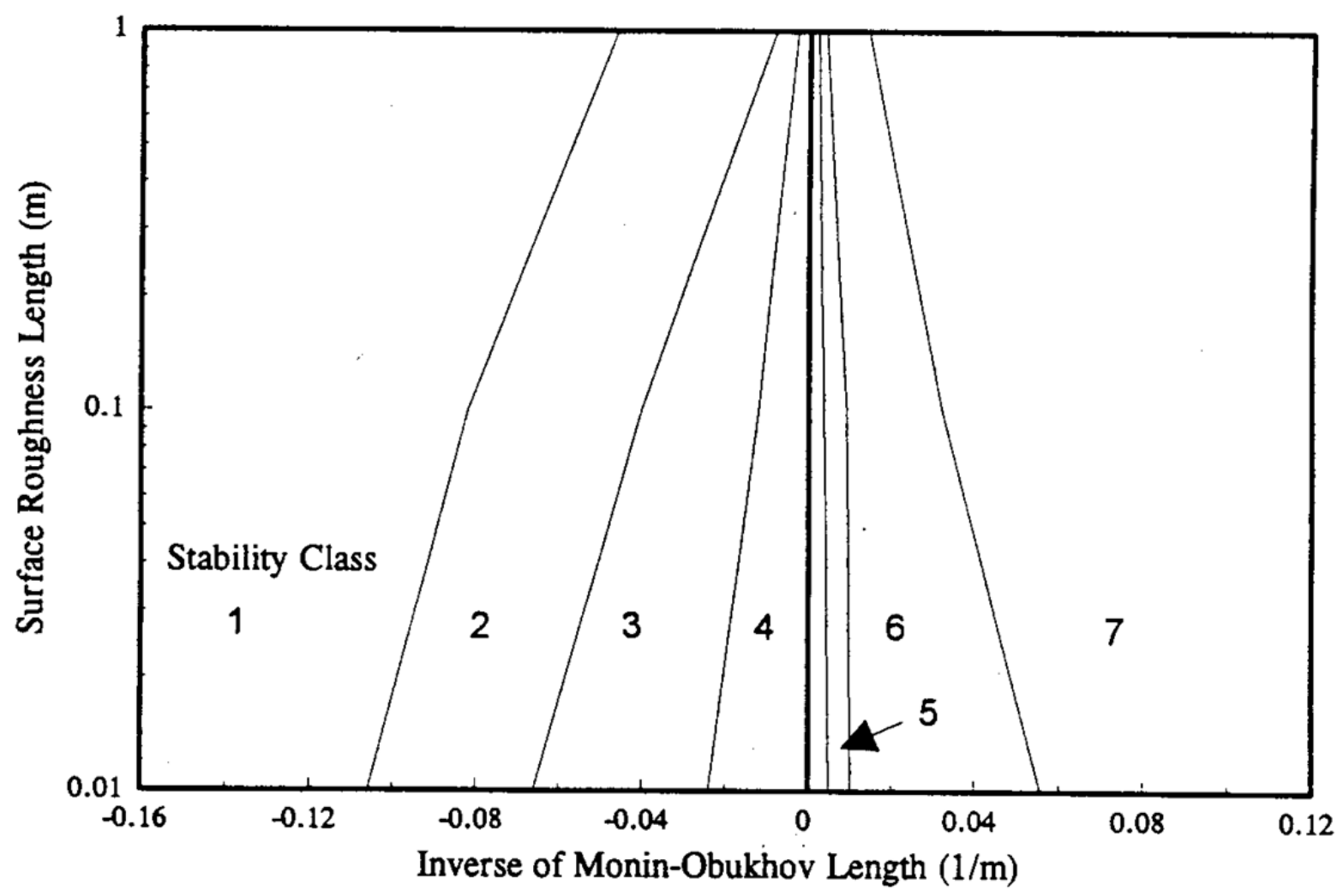

Figure 1. Relationship between Stability Class and M-O Length as a Function of Surface Roughness Length (Golder 1972) 


$$
\mathrm{v}_{\mathrm{s}}=\frac{\left(\rho-\rho_{\mathrm{AIR}}\right) \mathrm{g} \mathrm{d}_{\mathrm{p}}^{2} \mathrm{c}_{2} \mathrm{~S}_{\mathrm{CF}}}{18 \mu}
$$

where $\quad \rho=$ the particle density $\left(\mathrm{g} / \mathrm{cm}^{3}\right)$

$\rho_{\text {AIR }}=$ the air density $\left(=1.2 \times 10^{-3} \mathrm{~g} / \mathrm{cm}^{3}\right)$

$\mathrm{d}_{\mathrm{p}}=$ the mass mean particle diameter $(\mu \mathrm{m})$

$\mu=$ the absolute viscosity of air $\left(=1.81 \times 10^{-4} \mathrm{~g} / \mathrm{cm} / \mathrm{s}\right)$

$\mathrm{c}_{2}=$ air units conversion constant $\left(=1 \times 10^{-8} \mathrm{~cm}^{2} / \mu \mathrm{m}^{2}\right)$

$\mathrm{S}_{\mathrm{CF}}=$ the slip correction factor, which is computed as

$$
\mathrm{S}_{\mathrm{CF}}=1+\frac{2 \mathrm{X}_{2}\left(\mathrm{a}_{1}+\mathrm{a}_{2} \exp \left(-\frac{\mathrm{a}_{3} \mathrm{~d}_{\mathrm{p}}}{\mathrm{x}_{2}}\right)\right)}{10^{-4} \mathrm{~d}_{\mathrm{p}}}
$$

where $\mathrm{x}_{2}, \mathrm{a}_{1}, \mathrm{a}_{2}$, and $\mathrm{a}_{3}$ are constants with values of $6.5 \times 10^{-6}, 1.257,0.4$, and $0.55 \times 10^{-4}$, respectively.

The gravitational settling velocity thus estimated is shown in Table 1 for a range of mass mean particle diameters and densities. It can be seen that as particle mass (the product of volume and density) increases, the settling velocity increases and becomes a dominant contributor to the deposition velocity.

Table 1. Settling velocities of particles of various diameter and density, estimated for stability class D and $3 \mathrm{~cm}$ surface roughness

$\begin{array}{ccccc}\begin{array}{c}\text { Mass Mean } \\ \begin{array}{c}\text { Particle } \\ \text { Diameter }(\mu \mathrm{m})\end{array}\end{array} & \begin{array}{c}\text { Density } \\ \left(\mathrm{g} / \mathrm{cm}^{3}\right)\end{array} & \begin{array}{c}\text { Set. Vel. } \\ (\mathrm{m} / \mathrm{s})\end{array} & \begin{array}{c}\text { DV } \\ (\mathrm{m} / \mathrm{s})\end{array} & \begin{array}{c}\text { Set. Vel. as } \\ \text { Fraction of } \\ \text { DV (\%) }\end{array} \\ 1 & 1 & 0.000035 & 0.0025 & 1 \% \\ 5 & 1 & 0.000776 & 0.0032 & 25 \% \\ 10 & 1 & 0.003057 & 0.0052 & 59 \% \\ 1 & 3 & 0.000105 & 0.0026 & 4 \% \\ 5 & 3 & 0.002331 & 0.0045 & 51 \% \\ 10 & 3 & 0.009177 & 0.0109 & 84 \% \\ 1 & 5 & 0.000175 & 0.0026 & 7 \% \\ 5 & 5 & 0.003886 & 0.0060 & 65 \% \\ 10 & 5 & 0.015298 & 0.0167 & 92 \%\end{array}$

The transfer resistance is used as a mathematical device to establish an upper limit on the deposition velocity. Both $r_{a}$ and $r_{s}$ become small as the wind speed (and therefore the friction velocity) increases. If the transfer resistance is set to zero for neutral conditions when the ratio of $\mathrm{U} / \mathrm{u} *$ is typically about 10 , then the dry DV computed using Equation (2) increases from about $0.006 \mathrm{~m} / \mathrm{s}$ for a wind speed of $1 \mathrm{~m} / \mathrm{s}$ to greater than $0.06 \mathrm{~m} / \mathrm{s}$ when the wind speed is $10 \mathrm{~m} / \mathrm{s}$. Deposition velocities at the upper end of this range are higher than normally assumed for most reactive gases, and the entire range of deposition velocities is above the range of deposition velocities measured for fine particles $(\sim 1 \mu \mathrm{m})$ and nonreactive 
gases. Assuming transfer resistances of $10 \mathrm{~s} / \mathrm{m}$ for reactive gases and $100 \mathrm{~s} / \mathrm{m}$ for fine particles yields dry deposition velocities that are more consistent with reported values.

Separate dry deposition velocities are computed for each type of material in GENII. If the material exists simultaneously in more than one form, then GENII computes a weighted-average dry deposition velocity. The dry DV is the weighted average of dry deposition velocities computed for nonreactive gases, reactive gases, and particles. The averaging weights for each form are based on the fraction of the material in the form. These fractions are input parameters entered by the user. The fractions are constant during a model run. For the analyses here, each particle has only one form. 


\section{Parametric Calculations for SRS Conditions}

Calculations were run for SRS using GENII. The particle size distribution released from hypothetical accidents is, of course, unknown. A parametric approach was taken here, as suggested by Elliott (2012). For this set of calculations, a range of particle sizes were evaluated $(1,5$, and $10 \mu \mathrm{m}$ mass mean diameters) and, for each, a range of particle densities $\left(1,3\right.$, and $\left.5 \mathrm{~g} / \mathrm{cm}^{2}\right)$. Dry DV does not vary greatly for particles in the range of 0.1 to $1 \mu \mathrm{m}$ activity median aerodynamic diameter AMAD (Sehmel 1984); in this range the mass mean diameter and AMAD are similar.

As discussed above, the DV is a function of several site-specific parameters, which include the local meteorology (wind speeds and stabilities) and local surface roughness.

GENII input usually includes local temperature and hourly mixing height. The temperature information is used in GENII to estimate plume rise, to adjust wind profiles, and to control wet scavenging of gases. For the current task of estimating dry deposition velocities, these functions are not required; therefore, surrogate temperature and ceiling height data from the Hanford Site were used to fill the data fields but were not used in the calculations.

The representation of surface roughness is a critical first step in many meteorological, wind engineering, and pollutant dispersion modeling activities. It provides an estimate of the drag and turbulent mixing associated with the underlying surface. The roughness length $\left(z_{o}\right)$ is a key parameter in the logarithmic velocity profile based on similarity theory and is commonly used in many models to specify the boundary conditions. The roughness length is directly related to the overall drag of the surface. Mathematically, it represents the distance above the displacement height plane at which the velocity goes to zero. For an initial approximation of the surface roughness, a value of $1 / 10$ of the height of the local roughness elements (trees, buildings, etc.) is often used.

The SRS is in a broad, mostly-forested area. A general rule of thumb is that forested areas have surface roughness values above $20 \mathrm{~cm}(0.2 \mathrm{~m})$. However, the numerical roughness is increased by the topographic relief. Some of the SRS operating areas are in open areas where the local surface roughness may be less, although the "effective" surface roughness may be larger because of the continuing influence of the forests upwind. In order to evaluate the influence of the surface roughness on the deposition velocity, an initial parametric analysis was performed using four surface roughness values. These were 3 , 30,100 , and $200 \mathrm{~cm}(0.03,0.3,1$, and $2 \mathrm{~m})$, as suggested by Elliott (2012). 


\section{Results}

The parameters evaluated include three stability classes $(\mathrm{D}, \mathrm{E}$, and $\mathrm{F})$, four wind speeds $(0.5,1,1.5$, and $2.0 \mathrm{~m} / \mathrm{s})$, three particle sizes $(1,5$, and $10 \mu \mathrm{m}$ mass mean diameter), three particle densities $(1,3$, and $\left.5 \mathrm{~g} / \mathrm{cm}^{3}\right)$, and four surface roughness lengths $(3,30,100$, and $200 \mathrm{~cm})$. This results in a total of 432 individual estimates of dry deposition velocity. These results are presented in Table 2.

Evaluation of the sensitivity of each of these input parameters to the calculated dry DV is presented in the following series of figures. (Note that the scale changes for each figure.)

Figures 2 and 3 illustrate the range of influence of particle size on DV for surface roughness of $3 \mathrm{~cm}$. In Figure 2, dry DV as a function of wind speed is shown for $1 \mu \mathrm{m}$ particles over a range of stability classes and particle densities. For these small particles, there is not much influence on the DV of particle density; wind speed is the dominant influence. In Figure 3, a similar plot is made but with $10 \mu \mathrm{m}$ particles; it is clear that particles of density $3 \mathrm{~g} / \mathrm{cm}^{3}$ deposit about twice as rapidly as particles of density 1 $\mathrm{g} / \mathrm{cm}^{3}$, and that particles of density $5 \mathrm{~g} / \mathrm{cm}^{3}$ deposit about four times faster than particles of density 1 $\mathrm{g} / \mathrm{cm}^{3}$. For these large massive particles, there is a low influence of stability/wind speed but high influence of gravitational settling.

Figures 4 and 5 are parallel to Figures 2 and 3, but for surface roughness of $100 \mathrm{~cm}$. In Figure 4, dry DV as a function of wind speed is shown for $1 \mu \mathrm{m}$ particles over a range of stability classes and particle densities. For these small particles, there is not much influence on the DV of particle density or stability class; the major influence is wind speed. In Figure 5, a similar plot is made but with $10 \mu \mathrm{m}$ particles; this figure is more emphatic than Figure 3 that particle density is more important than either wind speed or stability class. Also in comparing Figures 2 and 3 with 4 and 5, we can see that a surface roughness change from $3 \mathrm{~cm}$ (a flat field) to $100 \mathrm{~cm}$ (a forested area) has only about a factor of two impact on the deposition velocity.

Figures 6 and 7 present DV as functions of surface roughness, for particles with densities of 1 and 5 $\mathrm{g} / \mathrm{cm}^{3}$ respectively. In Figure 6, we can see that DV increases slightly with wind speed and particle size, as already seen in Figures 2 and 4; surface roughness from 3 to $200 \mathrm{~cm}$ has only about a factor of two influence on the deposition velocity. Figure 7 is similar. For dense particles, DV increases slightly with wind speed and by about a factor of two over the range of particle sizes. Again, surface roughness has only about a factor of two influence over the range 3 to $200 \mathrm{~cm}$, slightly less for the larger particles. Figures 8 and 9 are parallel to Figures 6 and 7 but for Class F. There is little difference between these sets of figures; the DV is slightly lower with Class F than Class D, more obviously with the smaller particles. The general conclusions, that DV increases slightly with wind speed and particle size and surface roughness has about a factor of two influence over the range 0.03 to $2 \mathrm{~m}$, are the same.

These findings are repeated in Figure 10. Figure 10 provides DV as a function of particle mass (volume multiplied by density) for various wind speed/stability combinations. In this figure, particle diameter and density are combined into one term, mass. Over the several order-of-magnitude range illustrated using particles ranging from $1 \mathrm{~g} / \mathrm{cm}^{3}$ density and $1 \mu \mathrm{m}$ diameter to $5 \mathrm{~g} / \mathrm{cm}^{3}$ density and $10 \mu \mathrm{m}$ diameter, DV varies by about a factor of five. Stability and wind speed together account for about a factor of five as well; the overall change in DV shown is about a factor of 25. Surface roughness within each stability/wind speed combination accounts for only about a factor of two. 
Table 2. Dry DV (m/s) evaluated as a function of particle diameter, particle density, surface roughness, wind speed, and atmospheric stability class.

\begin{tabular}{|c|c|c|c|c|c|c|c|c|c|c|}
\hline \multirow{3}{*}{$\begin{array}{c}\mathrm{Z}_{0} \\
(\mathrm{~cm})\end{array}$} & \multirow{3}{*}{$\begin{array}{l}\text { Wind } \\
\text { Speed } \\
(\mathrm{m} / \mathrm{s})\end{array}$} & \multicolumn{9}{|c|}{$1 \mu \mathrm{m}$ particle diameter } \\
\hline & & \multicolumn{3}{|c|}{$\begin{array}{c}\text { density }=1 \mathrm{~g} / \mathrm{cm}^{3} \\
\text { Stability Class }\end{array}$} & \multicolumn{3}{|c|}{$\begin{array}{c}\text { density }=3 \mathrm{~g} / \mathrm{cm}^{3} \\
\text { Stability Class }\end{array}$} & \multicolumn{3}{|c|}{$\begin{array}{c}\text { density }=5 \mathrm{~g} / \mathrm{cm}^{3} \\
\text { Stability Class }\end{array}$} \\
\hline & & $\mathrm{D}$ & $\mathrm{E}$ & $\mathrm{F}$ & $\mathrm{D}$ & $\mathrm{E}$ & $\mathrm{F}$ & $\mathrm{D}$ & $\mathrm{E}$ & $\mathrm{F}$ \\
\hline 3 & 0.5 & $9.13 \mathrm{E}-04$ & $8.33 E-04$ & $6.50 \mathrm{E}-04$ & $9.75 \mathrm{E}-04$ & $8.94 \mathrm{E}-04$ & $7.13 E-04$ & $1.04 \mathrm{E}-03$ & $9.56 \mathrm{E}-04$ & $7.75 E-04$ \\
\hline 3 & 1 & $2.50 \mathrm{E}-03$ & $2.32 \mathrm{E}-03$ & $1.89 \mathrm{E}-03$ & $2.56 \mathrm{E}-03$ & $2.38 \mathrm{E}-03$ & $1.95 \mathrm{E}-03$ & $2.62 \mathrm{E}-03$ & $2.44 \mathrm{E}-03$ & $2.02 \mathrm{E}-03$ \\
\hline 3 & 1.5 & 3.33E-03 & $3.11 \mathrm{E}-03$ & $2.59 \mathrm{E}-03$ & 3.39E-03 & $3.18 \mathrm{E}-03$ & $2.65 \mathrm{E}-03$ & $3.45 \mathrm{E}-03$ & $3.24 \mathrm{E}-03$ & $2.71 \mathrm{E}-03$ \\
\hline 3 & 2 & $3.99 \mathrm{E}-03$ & 3.76E-03 & 3.17E-03 & 4.06E-03 & $3.82 \mathrm{E}-03$ & $3.24 \mathrm{E}-03$ & 4.12E-03 & $3.89 \mathrm{E}-03$ & $3.30 \mathrm{E}-03$ \\
\hline 30 & 0.5 & $1.95 \mathrm{E}-03$ & $1.78 \mathrm{E}-03$ & $1.48 \mathrm{E}-03$ & $2.01 \mathrm{E}-03$ & $1.84 \mathrm{E}-03$ & $1.54 \mathrm{E}-03$ & 2.07E-03 & $1.90 \mathrm{E}-03$ & $1.60 \mathrm{E}-03$ \\
\hline 30 & 1 & $4.31 \mathrm{E}-03$ & 4.06E-03 & 3.57E-03 & 4.37E-03 & $4.12 \mathrm{E}-03$ & $3.64 \mathrm{E}-03$ & 4.44E-03 & 4.19E-03 & $3.70 \mathrm{E}-03$ \\
\hline 30 & 1.5 & $5.32 \mathrm{E}-03$ & 5.06E-03 & 4.55E-03 & $5.38 \mathrm{E}-03$ & $5.13 \mathrm{E}-03$ & 4.61E-03 & $5.45 \mathrm{E}-03$ & 5.19E-03 & $4.68 \mathrm{E}-03$ \\
\hline 30 & 2 & $6.02 \mathrm{E}-03$ & 5.77E-03 & $5.26 \mathrm{E}-03$ & $6.09 \mathrm{E}-03$ & $5.84 \mathrm{E}-03$ & 5.33E-03 & $6.16 \mathrm{E}-03$ & 5.91E-03 & $5.40 \mathrm{E}-03$ \\
\hline 100 & 0.5 & $3.28 \mathrm{E}-03$ & 3.06E-03 & 2.67E-03 & $3.35 \mathrm{E}-03$ & $3.12 \mathrm{E}-03$ & $2.73 \mathrm{E}-03$ & $3.41 \mathrm{E}-03$ & $3.19 E-03$ & $2.79 \mathrm{E}-03$ \\
\hline 100 & 1 & $5.90 \mathrm{E}-03$ & 5.67E-03 & $5.24 \mathrm{E}-03$ & $5.96 \mathrm{E}-03$ & $5.74 \mathrm{E}-03$ & $5.30 \mathrm{E}-03$ & $6.03 \mathrm{E}-03$ & $5.80 \mathrm{E}-03$ & $5.37 \mathrm{E}-03$ \\
\hline 100 & 1.5 & $6.84 \mathrm{E}-03$ & $6.63 \mathrm{E}-03$ & $6.23 \mathrm{E}-03$ & $6.90 \mathrm{E}-03$ & $6.70 \mathrm{E}-03$ & $6.30 \mathrm{E}-03$ & $6.97 \mathrm{E}-03$ & $6.77 \mathrm{E}-03$ & $6.37 \mathrm{E}-03$ \\
\hline 100 & 2 & 7.43E-03 & 7.24E-03 & $6.88 \mathrm{E}-03$ & 7.50E-03 & 7.31E-03 & $6.95 \mathrm{E}-03$ & 7.56E-03 & 7.38E-03 & $7.02 \mathrm{E}-03$ \\
\hline 200 & 0.5 & 4.64E-03 & $4.29 \mathrm{E}-03$ & 3.70E-03 & 4.70E-03 & $4.36 \mathrm{E}-03$ & $3.76 \mathrm{E}-03$ & 4.77E-03 & $4.42 \mathrm{E}-03$ & $3.82 \mathrm{E}-03$ \\
\hline 200 & 1 & 7.06E-03 & 6.79E-03 & $6.28 \mathrm{E}-03$ & 7.13E-03 & $6.86 \mathrm{E}-03$ & $6.35 \mathrm{E}-03$ & 7.19E-03 & 6.93E-03 & 6.42E-03 \\
\hline 200 & 1.5 & 7.83E-03 & 7.61E-03 & $7.18 \mathrm{E}-03$ & 7.90E-03 & $7.68 \mathrm{E}-03$ & $7.25 \mathrm{E}-03$ & 7.97E-03 & $7.75 \mathrm{E}-03$ & $7.32 \mathrm{E}-03$ \\
\hline 200 & 2 & 8.29E-03 & 8.10E-03 & $7.73 \mathrm{E}-03$ & 8.36E-03 & 8.17E-03 & 7.80E-03 & 8.43E-03 & 8.24E-03 & 7.87E-03 \\
\hline
\end{tabular}


Table 2 continued: Dry DV (m/s) evaluated as a function of particle diameter, particle density, surface roughness, wind speed, and atmospheric stability class.

$5 \mu \mathrm{m}$ particle diameter

\begin{tabular}{|c|c|c|c|c|c|c|c|c|c|c|}
\hline \multirow{2}{*}{$\begin{array}{c}Z_{0} \\
(\mathrm{~cm})\end{array}$} & \multirow{2}{*}{$\begin{array}{l}\text { Wind } \\
\text { Speed } \\
(\mathrm{m} / \mathrm{s})\end{array}$} & \multicolumn{3}{|c|}{$\begin{array}{c}\text { density }=1 \mathrm{~g} / \mathrm{cm}^{3} \\
\text { Stability Class }\end{array}$} & \multicolumn{3}{|c|}{$\begin{array}{c}\text { density }=3 \mathrm{~g} / \mathrm{cm}^{3} \\
\text { Stability Class }\end{array}$} & \multicolumn{3}{|c|}{$\begin{array}{c}\text { density }=5 \mathrm{~g} / \mathrm{cm}^{3} \\
\text { Stability Class }\end{array}$} \\
\hline & & $\mathrm{D}$ & $\mathrm{E}$ & $\mathrm{F}$ & $\mathrm{D}$ & $\mathrm{E}$ & $\mathrm{F}$ & D & $\mathrm{E}$ & $\mathrm{F}$ \\
\hline 3 & 0.5 & 1.57E-03 & $1.49 \mathrm{E}-03$ & $1.32 \mathrm{E}-03$ & $3.00 \mathrm{E}-03$ & $2.92 \mathrm{E}-03$ & $2.76 \mathrm{E}-03$ & $4.46 \mathrm{E}-03$ & 4.39E-03 & $4.25 \mathrm{E}-03$ \\
\hline 3 & 1 & $3.15 \mathrm{E}-03$ & 2.97E-03 & $2.54 \mathrm{E}-03$ & $4.54 \mathrm{E}-03$ & $4.36 \mathrm{E}-03$ & $3.93 \mathrm{E}-03$ & 5.96E-03 & $5.78 \mathrm{E}-03$ & $5.35 \mathrm{E}-03$ \\
\hline 3 & 1.5 & 4.00E-03 & $3.78 \mathrm{E}-03$ & $3.25 \mathrm{E}-03$ & $5.42 \mathrm{E}-03$ & $5.20 \mathrm{E}-03$ & $4.66 \mathrm{E}-03$ & $6.85 \mathrm{E}-03$ & $6.62 \mathrm{E}-03$ & $6.08 \mathrm{E}-03$ \\
\hline 3 & 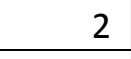 & 4.67E-03 & 4.44E-03 & $3.85 \mathrm{E}-03$ & $.12 \mathrm{E}-03$ & $.87 E-03$ & $5.27 \mathrm{E}-03$ & $.56 \mathrm{E}-03$ & 7.32E-03 & $6.71 \mathrm{E}-03$ \\
\hline 30 & 0.5 & 2.60E-03 & $2.43 \mathrm{E}-03$ & $2.13 \mathrm{E}-03$ & 3.99E-03 & $3.82 \mathrm{E}-03$ & $3.52 \mathrm{E}-03$ & $5.41 \mathrm{E}-03$ & $5.24 \mathrm{E}-03$ & 4.96E-03 \\
\hline 30 & 1 & 4.99E-03 & $.74 E-03$ & $4.24 \mathrm{E}-03$ & $.43 \mathrm{E}-03$ & $.17 E-03$ & $5.66 \mathrm{E}-03$ & 7.87E-03 & $7.60 \mathrm{E}-03$ & $7.08 \mathrm{E}-03$ \\
\hline 30 & .5 & & & & & & & & & \\
\hline 30 & 2 & $6.74 \mathrm{E}-03$ & $6.48 \mathrm{E}-03$ & 5.97E-03 & $8.23 \mathrm{E}-03$ & 7.97E-03 & 7.44E-03 & $9.73 \mathrm{E}-03$ & $9.46 \mathrm{E}-03$ & $8.92 \mathrm{E}-03$ \\
\hline 100 & .5 & $3.95 \mathrm{E}-03$ & $3.72 \mathrm{E}-03$ & 3.33E-03 & $5.36 \mathrm{E}-03$ & $5.12 \mathrm{E}-03$ & $4.72 \mathrm{E}-03$ & 6.77E-03 & $6.54 \mathrm{E}-03$ & $6.13 \mathrm{E}-03$ \\
\hline 100 & 1 & $6.61 \mathrm{E}-03$ & $6.37 \mathrm{E}-03$ & $5.94 \mathrm{E}-03$ & $8.09 \mathrm{E}-03$ & $7.86 \mathrm{E}-03$ & $7.41 \mathrm{E}-03$ & $9.59 \mathrm{E}-03$ & $9.34 \mathrm{E}-03$ & $8.88 \mathrm{E}-03$ \\
\hline 100 & .5 & 7.56E-03 & 7.35E-03 & $6.95 \mathrm{E}-03$ & $9.07 \mathrm{E}-03$ & $8.86 \mathrm{E}-03$ & $8.44 \mathrm{E}-03$ & 1.06E-02 & $1.04 \mathrm{E}-02$ & $9.95 \mathrm{E}-03$ \\
\hline 100 & 2 & 8.16E-03 & 7.97E-03 & 7.61E-03 & $9.68 \mathrm{E}-03$ & $9.49 \mathrm{E}-03$ & $9.12 \mathrm{E}-03$ & $1.12 \mathrm{E}-02$ & 1.10E-02 & $1.06 \mathrm{E}-02$ \\
\hline 200 & 0.5 & $5.33 \mathrm{E}-03$ & $7.86 \mathrm{E}-03$ & 4.37E-03 & $6.77 \mathrm{E}-03$ & $6.42 \mathrm{E}-03$ & $5.79 \mathrm{E}-03$ & $8.23 \mathrm{E}-03$ & $7.86 \mathrm{E}-03$ & $7.21 \mathrm{E}-03$ \\
\hline 200 & 1 & 7.79E-03 & $1.05 \mathrm{E}-02$ & 7.00E-03 & $9.30 \mathrm{E}-03$ & $9.03 \mathrm{E}-03$ & $8.50 \mathrm{E}-03$ & $1.08 \mathrm{E}-02$ & $1.05 \mathrm{E}-02$ & $1.00 \mathrm{E}-02$ \\
\hline 200 & 1.5 & 8.57E-03 & $1.14 \mathrm{E}-02$ & & & $9.88 \mathrm{E}-03$ & & 1.16E-02 & $1.14 \mathrm{E}-02$ & 1.10E-02 \\
\hline 200 & 2 & $9.02 \mathrm{E}-03$ & 1.19E-02 & 8.46E-03 & $1.06 \mathrm{E}-02$ & $1.04 \mathrm{E}-02$ & $1.00 \mathrm{E}-02$ & $1.21 \mathrm{E}-02$ & 1.19E-02 & 1.15E-02 \\
\hline
\end{tabular}


Table 2 continued: Dry DV (m/s) evaluated as a function of particle diameter, particle density, surface roughness, wind speed, and atmospheric stability class.

$10 \mu \mathrm{m}$ particle diameter

\begin{tabular}{|c|c|c|c|c|c|c|c|c|c|c|}
\hline \multirow{2}{*}{$\begin{array}{c}Z_{0} \\
(\mathrm{~cm})\end{array}$} & \multirow{2}{*}{$\begin{array}{l}\text { Wind } \\
\text { Speed } \\
(\mathrm{m} / \mathrm{s})\end{array}$} & \multicolumn{3}{|c|}{$\begin{array}{c}\text { density }=1 \mathrm{~g} / \mathrm{cm}^{3} \\
\text { Stability Class }\end{array}$} & \multicolumn{3}{|c|}{$\begin{array}{c}\text { density }=3 \mathrm{~g} / \mathrm{cm}^{3} \\
\text { Stability Class }\end{array}$} & \multicolumn{3}{|c|}{$\begin{array}{c}\text { density }=5 \mathrm{~g} / \mathrm{cm}^{3} \\
\text { Stability Class }\end{array}$} \\
\hline & & $\mathrm{D}$ & $\mathrm{E}$ & $\mathrm{F}$ & $\mathrm{D}$ & $\mathrm{E}$ & $\mathrm{F}$ & D & $\mathrm{E}$ & $\mathrm{F}$ \\
\hline 3 & 0.5 & 3.67E-03 & 3.60E-03 & $3.45 \mathrm{E}-03$ & $9.56 \mathrm{E}-03$ & 9.51E-03 & $9.41 \mathrm{E}-03$ & $1.56 \mathrm{E}-02$ & $1.55 \mathrm{E}-02$ & 1.55E-02 \\
\hline 3 & 1 & 5.20E-03 & $5.02 \mathrm{E}-03$ & 4.59E-03 & 1.09E-02 & 1.07E-02 & $1.03 \mathrm{E}-02$ & 1.67E-02 & $1.65 \mathrm{E}-02$ & 1.62E-02 \\
\hline 3 & 1.5 & $6.08 \mathrm{E}-03$ & $5.86 \mathrm{E}-03$ & $5.32 \mathrm{E}-03$ & $1.18 \mathrm{E}-02$ & $1.16 \mathrm{E}-02$ & 1.10E-02 & $1.76 \mathrm{E}-02$ & $1.74 \mathrm{E}-02$ & $1.68 \mathrm{E}-02$ \\
\hline 3 & 2 & $6.79 \mathrm{E}-03$ & $6.55 \mathrm{E}-03$ & $5.94 \mathrm{E}-03$ & $1.25 \mathrm{E}-02$ & $1.23 \mathrm{E}-02$ & 1.17E-02 & $1.83 \mathrm{E}-02$ & $1.81 \mathrm{E}-02$ & $1.75 \mathrm{E}-02$ \\
\hline 30 & 0.5 & $4.65 \mathrm{E}-03$ & $4.48 \mathrm{E}-03$ & 4.19E-03 & $1.04 \mathrm{E}-02$ & $1.02 \mathrm{E}-02$ & $9.97 \mathrm{E}-03$ & $1.62 \mathrm{E}-02$ & $1.61 \mathrm{E}-02$ & $1.59 \mathrm{E}-02$ \\
\hline 30 & 1 & 7.10E-03 & $6.84 \mathrm{E}-03$ & $6.32 \mathrm{E}-03$ & $1.28 \mathrm{E}-02$ & $.25 \mathrm{E}-02$ & 1.20E-02 & $1.86 \mathrm{E}-02$ & 1.83E-02 & 1.78E-02 \\
\hline 30 & 1.5 & $8.18 \mathrm{E}-03$ & 7.91E-03 & 7.36E-03 & $1.40 \mathrm{E}-02$ & 1.37E-02 & $1.31 \mathrm{E}-02$ & $1.99 \mathrm{E}-02$ & $1.96 \mathrm{E}-02$ & $1.89 \mathrm{E}-02$ \\
\hline 30 & 2 & $8.93 \mathrm{E}-03$ & 8.67E-03 & $8.13 \mathrm{E}-03$ & $1.48 \mathrm{E}-02$ & $1.45 \mathrm{E}-02$ & $1.40 \mathrm{E}-02$ & $2.07 \mathrm{E}-02$ & $2.04 \mathrm{E}-02$ & $1.98 \mathrm{E}-02$ \\
\hline 100 & .5 & $6.02 \mathrm{E}-03$ & $5.78 \mathrm{E}-03$ & $5.38 \mathrm{E}-03$ & 1.17E-02 & $1.14 \mathrm{E}-02$ & 1.10E-02 & $1.75 \mathrm{E}-02$ & $1.72 \mathrm{E}$ & $1.69 \mathrm{E}-02$ \\
\hline 100 & 1 & 8.79E-03 & 8.55E-03 & 8.09E-03 & 1.47E-02 & $1.44 \mathrm{E}-02$ & 1.39E-02 & 2.06E-02 & 2.03E-02 & 1.98E-02 \\
\hline 100 & 1.5 & $9.78 \mathrm{E}-03$ & $9.56 \mathrm{E}-03$ & $9.15 \mathrm{E}-03$ & $1.58 \mathrm{E}-02$ & $1.55 \mathrm{E}-02$ & $1.51 \mathrm{E}-02$ & 2.17E-02 & $2.15 \mathrm{E}-02$ & $2.10 \mathrm{E}-02$ \\
\hline 100 & 2 & $1.04 \mathrm{E}-02$ & $1.02 \mathrm{E}-02$ & $9.83 \mathrm{E}-03$ & $1.64 \mathrm{E}-02$ & $1.62 \mathrm{E}-02$ & $1.58 \mathrm{E}-02$ & $2.24 \mathrm{E}-02$ & $2.22 \mathrm{E}-02$ & $2.18 \mathrm{E}-02$ \\
\hline 200 & .5 & $7.45 \mathrm{E}-03$ & $7.08 \mathrm{E}-03$ & $6.45 \mathrm{E}-03$ & $1.32 \mathrm{E}-02$ & $1.28 \mathrm{E}-02$ & $1.21 \mathrm{E}-02$ & $1.90 \mathrm{E}-02$ & $1.86 \mathrm{E}-02$ & $1.79 \mathrm{E}-02$ \\
\hline 200 & 1 & $1.00 \mathrm{E}-02$ & $9.74 \mathrm{E}-03$ & $9.20 \mathrm{E}-03$ & $1.60 \mathrm{E}-02$ & 1.57E-02 & $1.51 \mathrm{E}-02$ & $2.20 \mathrm{E}-02$ & 2.17E-02 & $2.11 \mathrm{E}-02$ \\
\hline 200 & 1.5 & $1.08 \mathrm{E}-02$ & $1.06 \mathrm{E}-02$ & $1.01 \mathrm{E}-02$ & 1.69E-02 & $1.66 \mathrm{E}-02$ & 1.61E-02 & $2.29 \mathrm{E}-02$ & 2.27E-02 & $2.21 \mathrm{E}-02$ \\
\hline 200 & 2 & $1.13 \mathrm{E}-02$ & $1.11 \mathrm{E}-02$ & 1.07E-02 & $1.74 \mathrm{E}-02$ & $1.72 \mathrm{E}-02$ & $1.68 \mathrm{E}-02$ & $2.34 \mathrm{E}-02$ & $2.32 \mathrm{E}-02$ & $2.28 \mathrm{E}-02$ \\
\hline
\end{tabular}




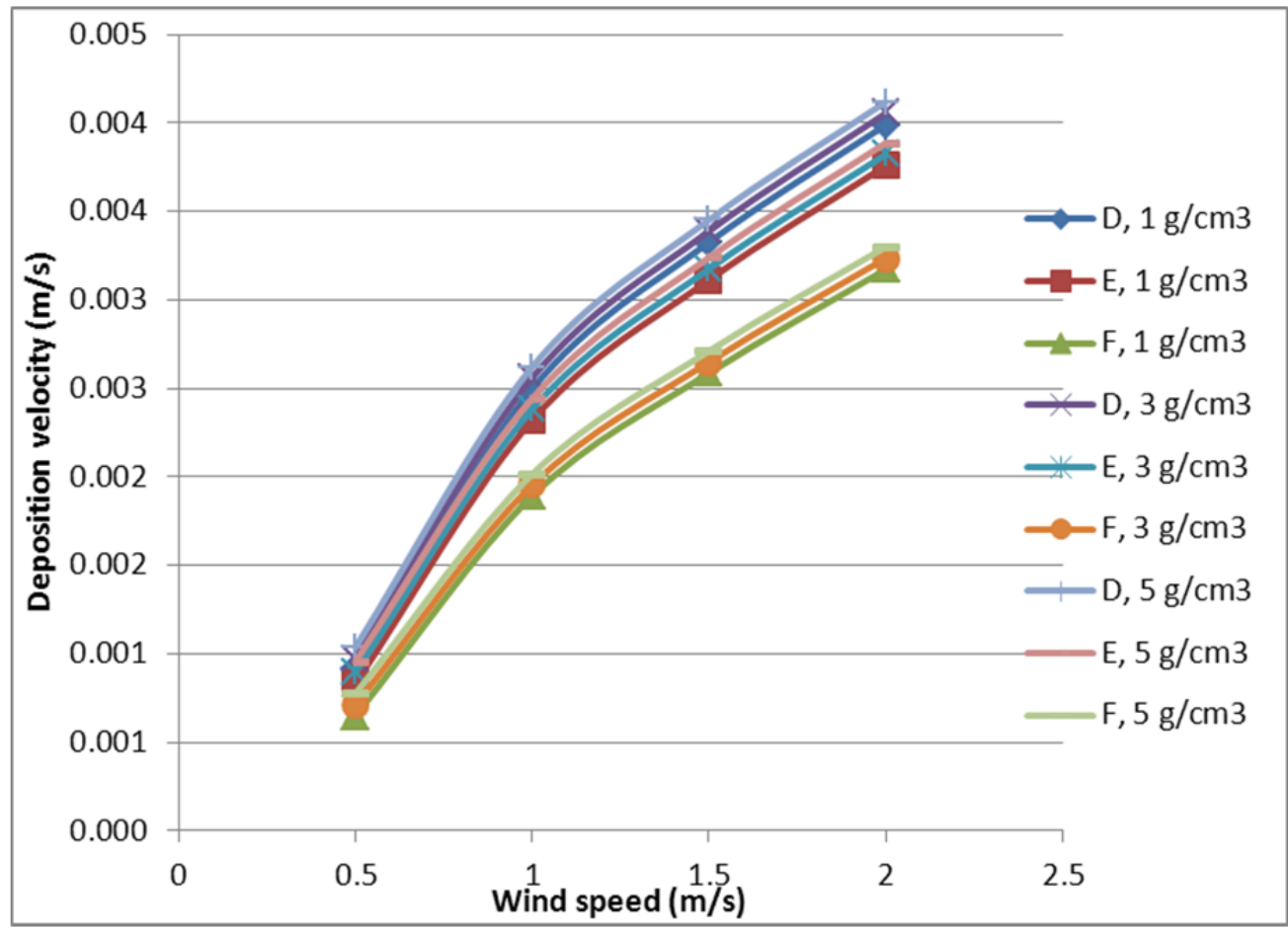

Figure 2. Variation of Dry DV as a Function of Wind Speed, Stability Class, and Particle Density; Developed for $1 \mu \mathrm{m}$ Particles and a Surface Roughness of $0.03 \mathrm{~m}$.

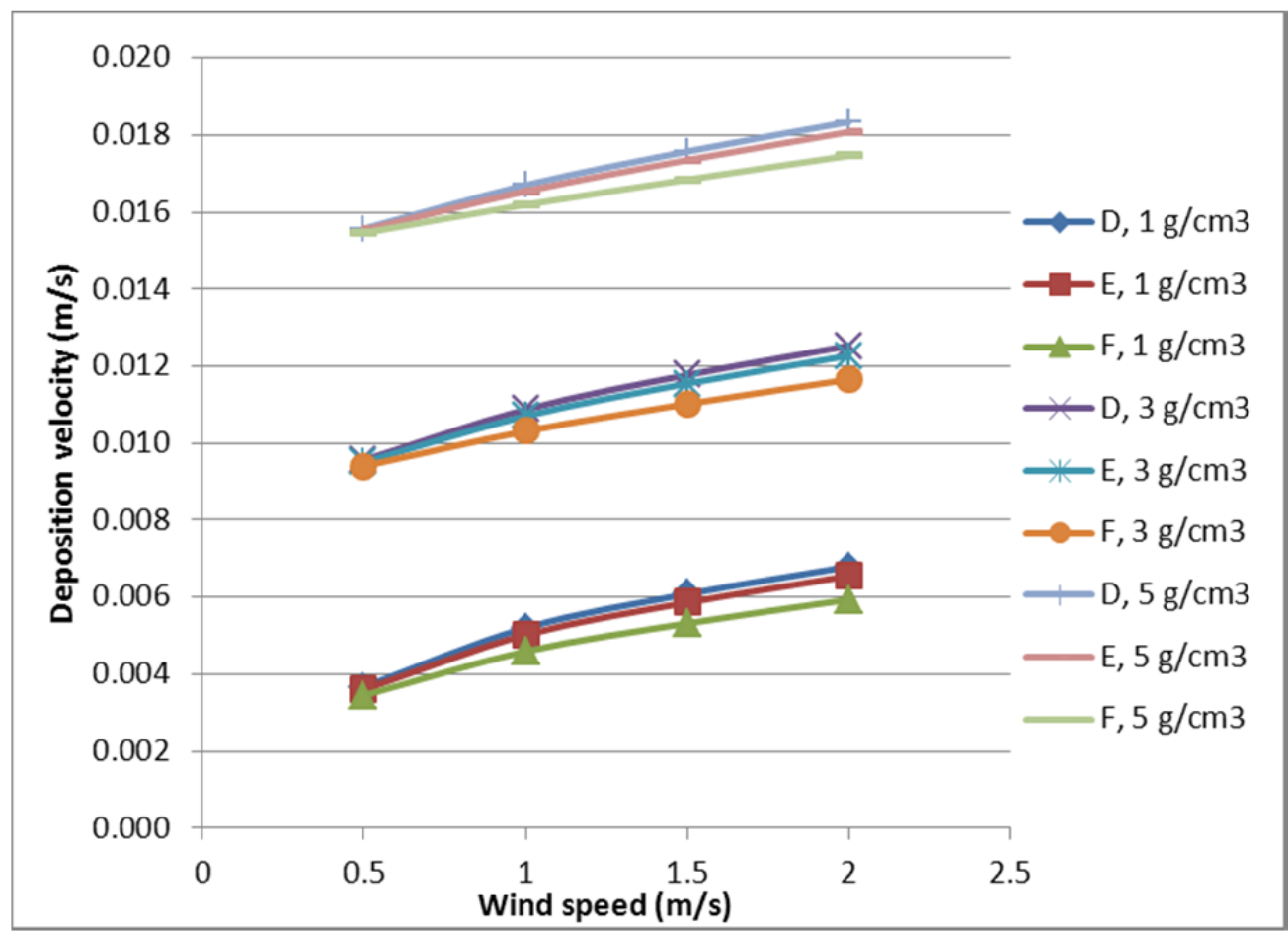

Figure 3. Variation of Dry DV as a Function of Wind Speed, Stability Class, and Particle Density; Developed for $10 \mu \mathrm{m}$ particles and a Surface Roughness of $0.03 \mathrm{~m}$. 


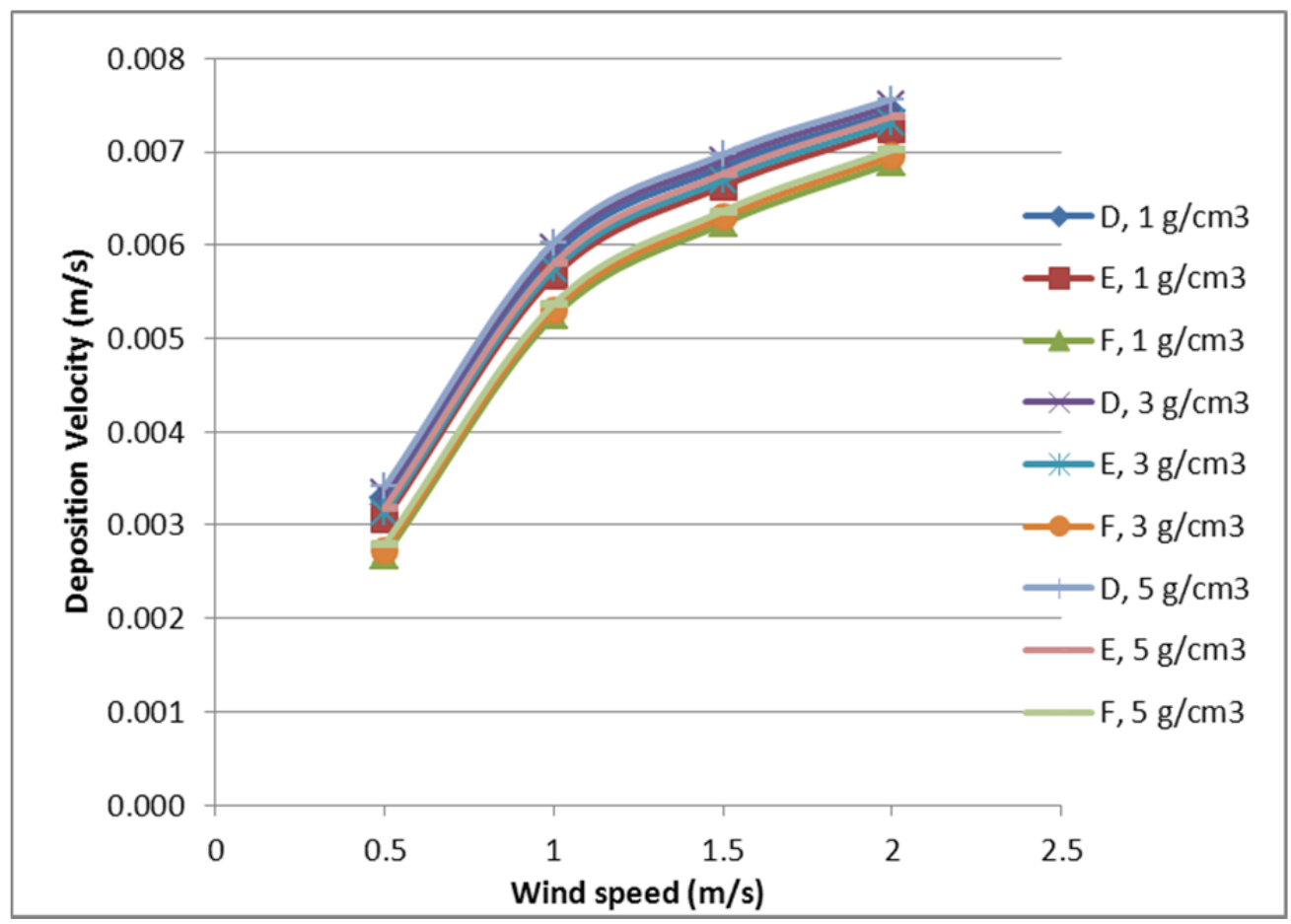

Figure 4. Variation of Dry DV as a Function of Wind Speed, Stability Class, and Particle Density; Developed for $1 \mu \mathrm{m}$ Particles and a Surface Roughness of $1 \mathrm{~m}$.

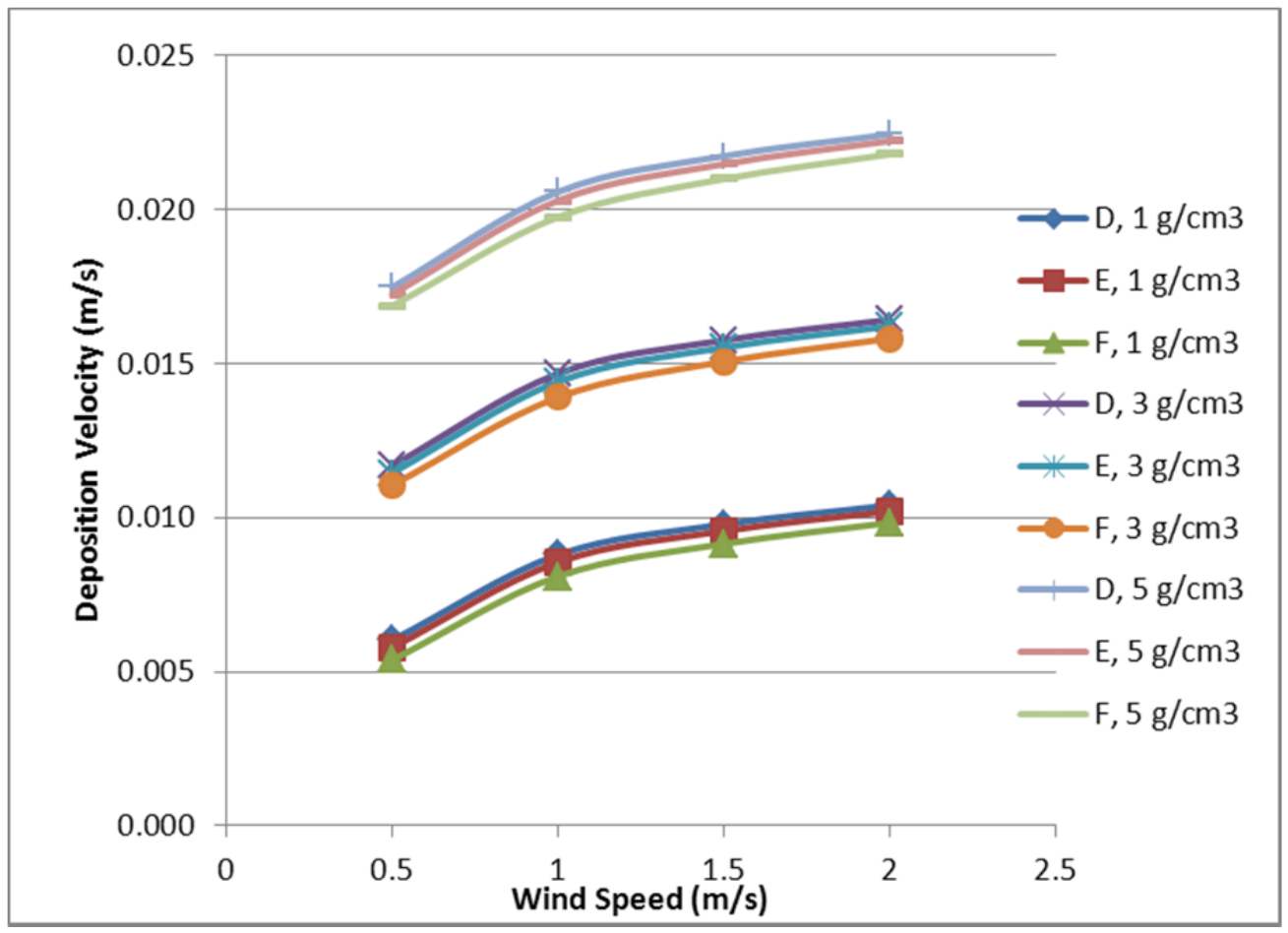

Figure 5. Variation of Dry DV as a Function of Wind Speed, Stability Class, and Particle Density; Developed for $10 \mu \mathrm{m}$ particles and a Surface Roughness of $1 \mathrm{~m}$. 


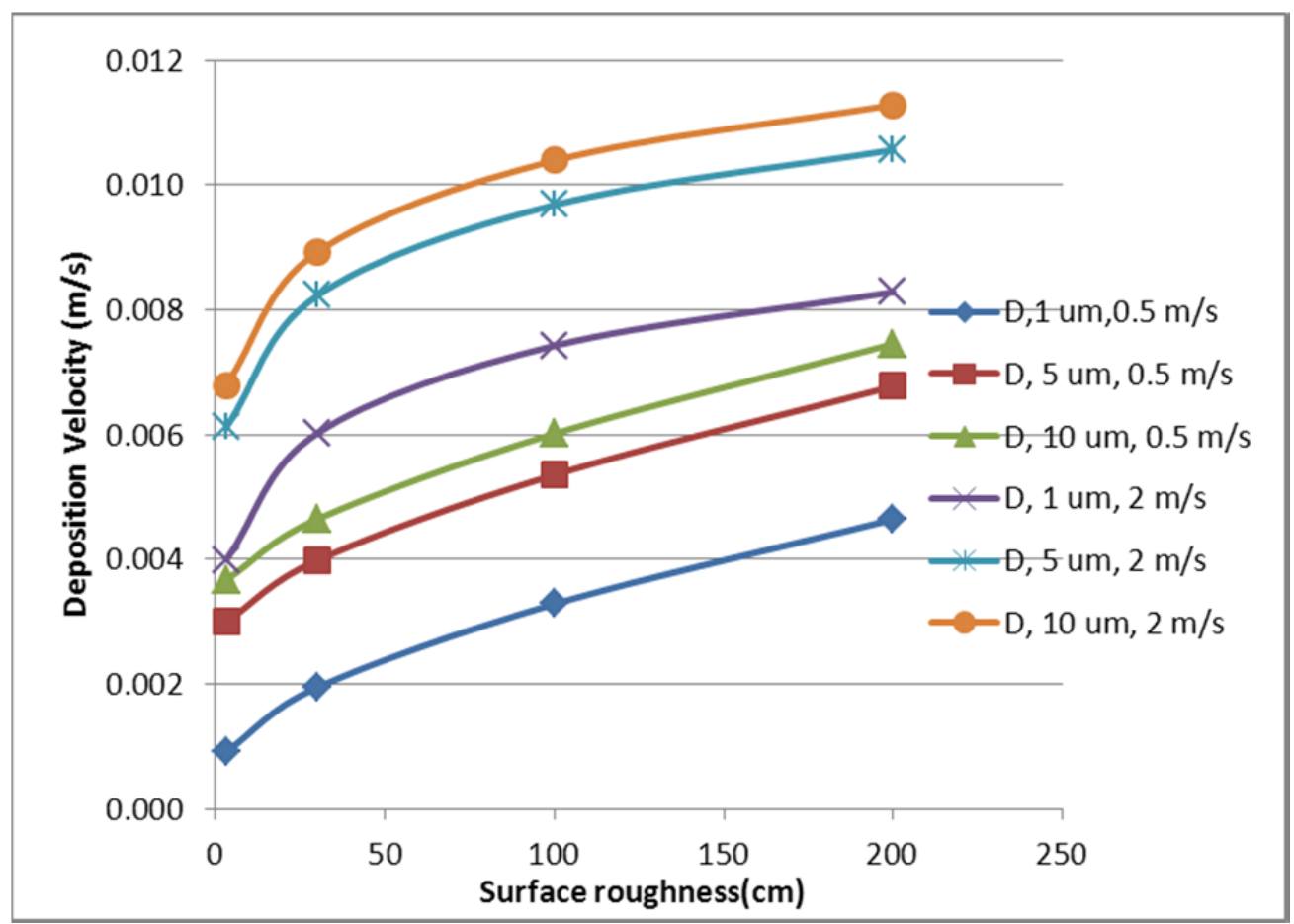

Figure 6. Variation of Dry DV as a Function of Surface Roughness; Developed for Particles of Density 1 $\mathrm{g} / \mathrm{cm}^{3}$, Stability Class D.

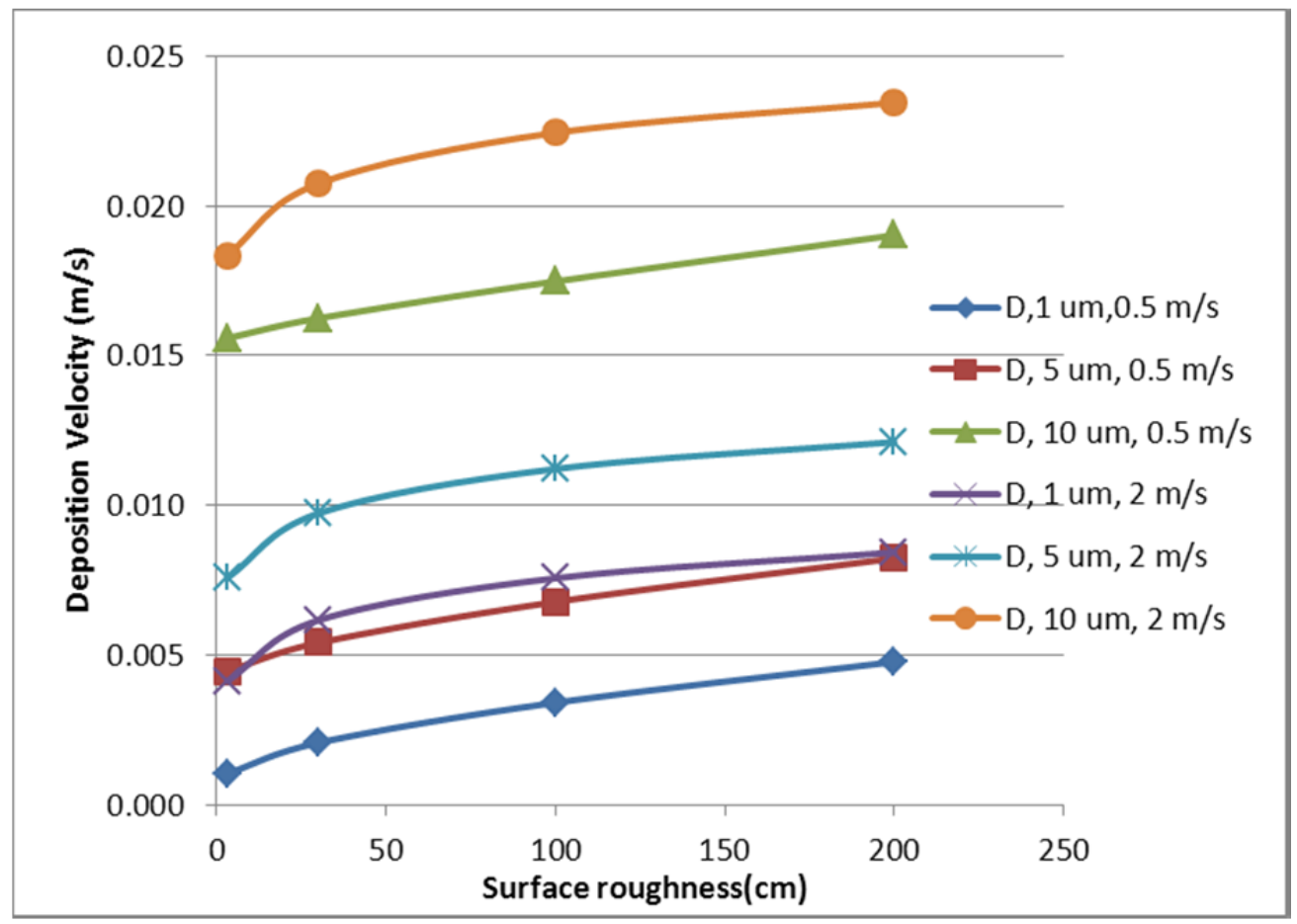

Figure 7. Variation of Dry DV as a Function of Surface Roughness; Developed for Particles of Density 5 $\mathrm{g} / \mathrm{cm}^{3}$, Stability Class D. 


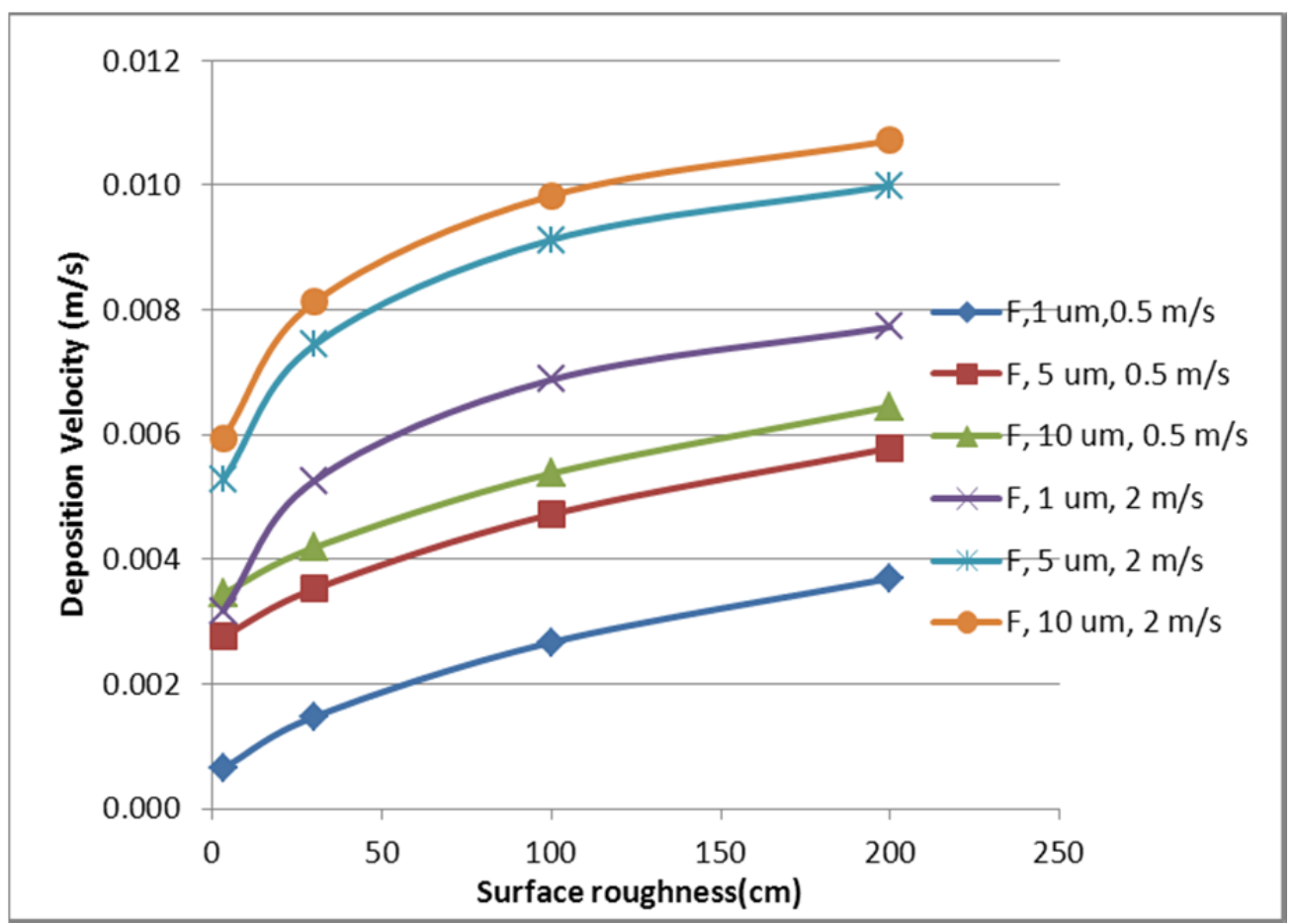

Figure 8 Variation of Dry DV as a Function of Surface Roughness; Developed for Particles of Density 1 $\mathrm{g} / \mathrm{cm}^{3}$, Stability Class F.

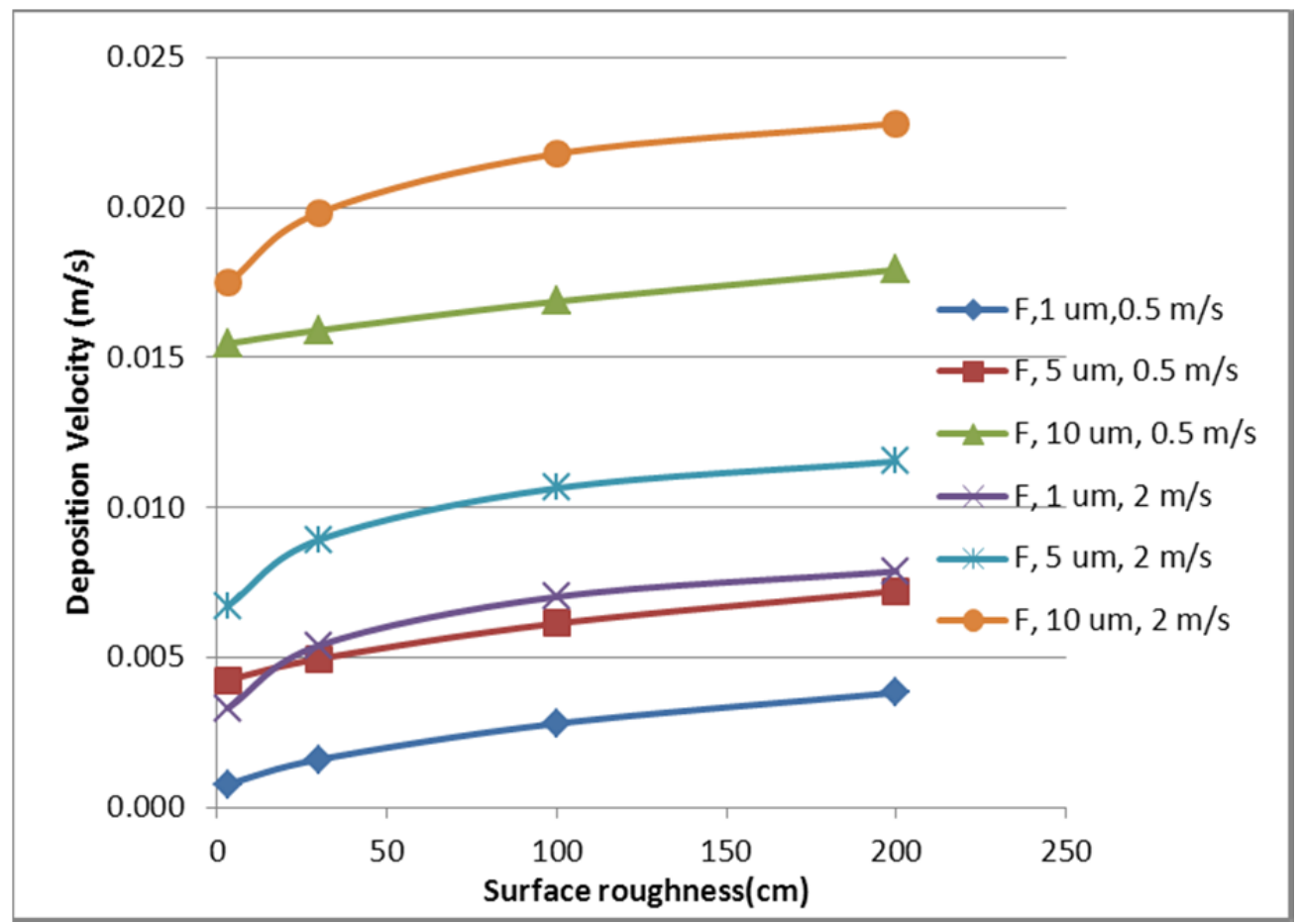

Figure 9 Variation of Dry DV as a Function of Surface Roughness; Developed for Particles of Density 5 $\mathrm{g} / \mathrm{cm}^{3}$, Stability Class F. 


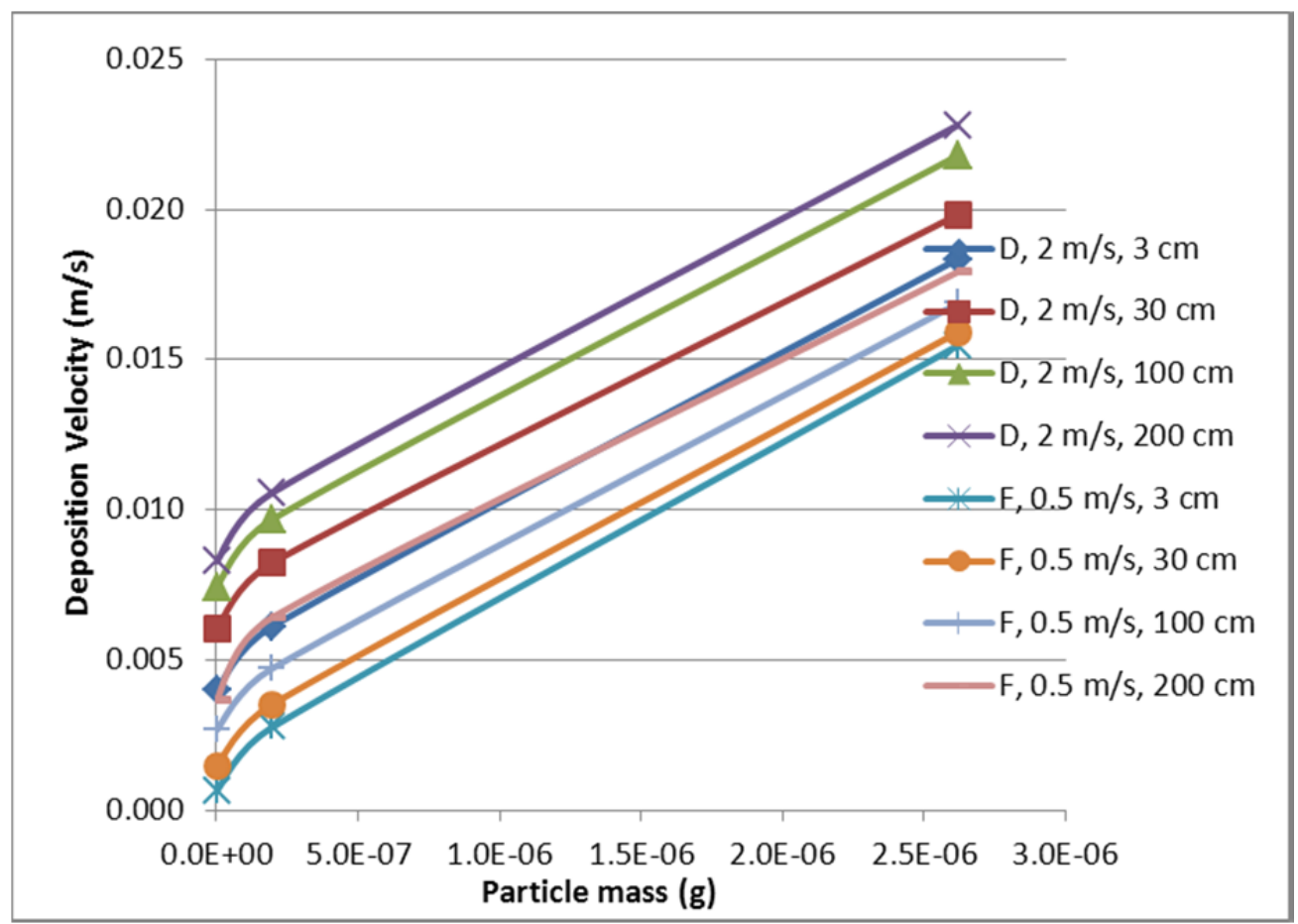

Figure 10 DV as a function of particle mass (volume*density) for various wind speed/stability combinations 


\section{Discussion}

This report is the first of two planned for the evaluation of dry deposition velocity (DV) for the Savannah River Site. In this report, a parametric analysis has been performed on DV by varying assumptions about surface roughness parameters and particle size and density. Meteorological conditions evaluated include atmospheric stability classes D, E, and F and wind speeds of $0.5,1.0,1.5$, and $3.0 \mathrm{~m} / \mathrm{s}$. Local surface roughness values ranging from 0.03 to 2 meters were evaluated. Particles with mass mean diameters of 1,5 , and 10 microns and densities of 1,3 , and $5 \mathrm{~g} / \mathrm{cm}^{3}$ were evaluated. The planned Part 2 of this analysis will investigate the DV using actual SRS meteorological data and estimate the DV anticipated to accompany $95^{\text {th }}$ percentile dispersion conditions.

Each of the parameters that were varied has an influence on the DV. Some parameters have a larger influence than others on DV for various combinations of conditions. Mass mean particle size and density (or, combined, the mean particle mass) have the greatest effect, because large particles are highly influenced by gravitational settling. Wind speed and stability class also have a relatively large influence; it is anticipated that the $95^{\text {th }}$ percentile conditions at SRS will be a highly stable, low wind combination, somewhat akin to the $0.5 \mathrm{~m} / \mathrm{s}$ and Class $\mathrm{F}$ combination included in this evaluation. These combinations, as illustrated in Figures $1-8$, tend to have the lowest values of DV. The influence of local surface roughness has a relatively minor impact for large particles - generally less than a factor of two over the range of surface roughness from 0.03 to $2 \mathrm{~m}$. For small, light particles, the surface roughness can impact the DV by factors of 2 to 4 for Class D and up to a factor of 5 for Class F.

It must be kept in mind that DV is only one factor in the final estimation of the concentration of materials in the atmosphere after a release; besides influencing DV itself, wind speed and stability are the major determining factors in downwind concentration. 


\section{References}

Aoyama M, K Hirose, Y Suzuki, H Inoue, and Y Sugimura. 1986. "High level radioactive nuclides in Japan in May." Nature 321:819-820.

Bondietti EA, Brantley JN. 1986. "Characteristics of Chernobyl radioactivity in Tennessee." Nature 322:313-314.

Bowen BM. 1996. Neutral Surface Layer Turbulence Over Complex Terrain, UCRL-JC-121086, Lawrence Livermore National Laboratory, Livermore, California.

Businger JA, JC Wyngaard, Y Izumi, EF Bradley. 1971. "Flux-Profile Relationships in the Atmospheric Surface Layer.” Journal of the Atmospheric Sciences 28(2):181-189.

Cambray RS, Cawse PA, Garland JA, Gibson AB, Johnson P, Lewis GNJ, Newton D, Salmon L, Wade BO. 1987. "Observations on radioactivity from the Chernobyl accident." Nuclear Energy 26:77-101.

DOE - U.S. Department of Energy. 2004. "MACCS2 Computer Code Application Guidance for Documented Safety Analysis Final Report.” DOE-EH-4.2.1.1-MACCS2-Code Guidance.

DOE - U.S. Department of Energy. 2011. "Identification of Non-Conservative Accident Analysis Parameters,” HSS Safety Bulletin No. 2011-02.

DOE - U.S. Department of Energy. 2012. "Software Evaluation of GENII V2.10 with FRAMES v1.7 for Inclusion in the DOE Safety Software Central Registry," HSS-CR-2011-01.

EPA - U.S. Environmental Protection Agency. 1995. "User's Guide for the Industrial Source Complex (ISC3) Dispersion Models Volume II - Description of Model Algorithms.” EPA-454/B-95-003b. Research Triangle Park, North Carolina.

Elliott S. 2012. "SRS-Specific Particle Deposition Velocity Calculaton Part 1," S-ESR-G-00017 Rev. 0, Savannah River Nuclear Solutions, Aiken, South Carolina.

Golder D. 1982. "Relations Among Stability Parameters in the Surface Layer." Boundary-Layer Meteorology 3(1):47-58.

Ludwick JD. 1964. "Investigation of the nature of I-131 in the atmosphere." In Hanford Radiological Sciences Research and Development Annual Report for 1963, eds CC Gamertsfelder and JK Green, HW-81746, General Electric Co., Hanford Atomic Products Operation, Richland, Washington.

Ludwick JD. “A portable boom-type air sampler.” In Pacific Northwest Laboratory Annual Report for 1966 to the USAEC Division of Biology and Medicine. Vol. II: Physical Sciences, Part 1, Atmospheric sciences, eds DW Pearce and MR Compton. BNWL-481 1; 1967: 87-92, Pacific Northwest Laboratory, Richland, Washington.

Monin AS and AM Obukhov. 1954. "Basic Laws of Turbulent Mixing in the Ground Layer of the Atmosphere.” Trans. Geophys, Inst. Akad. Nauk, USSR 151:163-187. 
Mueck K. 1988. "Variations in activity concentration and radionuclide ratio in air after the Chernobyl accident and its relevance to inhalation dose estimates." Radiation Protection Dosimetry 22:219- 229.

Napier BA, DL Strenge, JV Ramsdell, Jr, PW Eslinger, and CJ Fosmire. 2010. GENII Version 2 Software Design Document. PNNL-14584, Rev. 3, Pacific Northwest National Laboratory, Richland, WA.

Pacific Northwest National Laboratory (PNNL). 2009. GENII Software Quality Assurance Manual, Pacific Northwest National Laboratory, Richland, WA.

Panofsky HA, Dutton JA. 1984. Atmospheric Turbulence. J. Wiley \& Sons, New York.

Paulson CA. 1970. "The Mathematical Representation of Wind Speed and Temperature Profiles in the Unstable Atmospheric Surface Layer." Journal of Applied Meteorology 9(6):857-861.

Perkins RW. 1963. "Studies of radioiodine and other fallout radionuclides in air." In Hanford Radiological Sciences Research and Development Annual Report for 1962, eds CC Gamertsfelder, JK Green. HW-77609:3.36 -3.48, General Electric Co., Hanford Atomic Products Operation; Richland, Washington.

Perkins RW. 1964. "Physical and chemical forms of I-131 from fallout and chemical processing plants." In Hanford Radiological Sciences Research and Development Annual Report for 1963, eds

CC Gamertsfelder, JK Green. HW-81746:3.55-3.58, General Electric Co., Hanford Atomic Products Operation; Richland, Washington.

Ramsdell JV Jr., CA Simonen, and KW Burk. 1994. "Regional Atmospheric Transport Code for Hanford Emission Tracking (RATCHET).” PNWD-2224 HEDR, Pacific Northwest National Laboratory, Richland, Washington.

Sehmel GA. 1984. "Deposition and Resuspension," In Atmospheric Science and Power Production, ed Randerson D. DOE/TIC-27601, US Department of Energy, Springfield, Virginia.

Seinfeld JH. 1986. Atmospheric Chemistry and Physics of Air Pollution. John Wiley \& Sons, New York. Voilleque PG. 1979. Iodine species in reactor effluents and in the environment. EPRI-NP-1269, Palo Alto, CA: Electric Power Research Institute. 



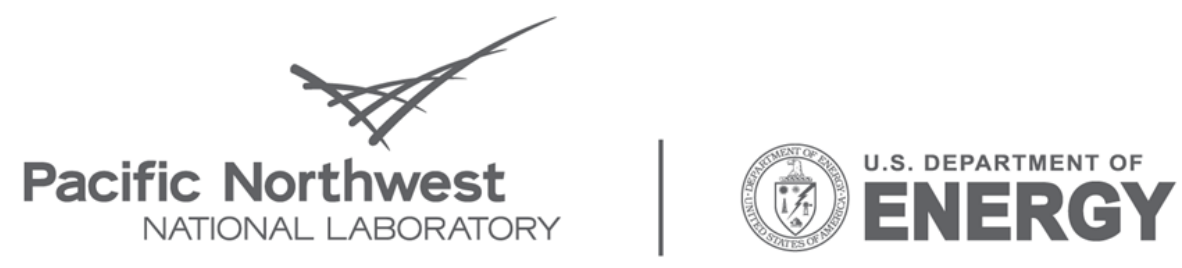

Proudly Operated by Battelle Since 1965

902 Battelle Boulevard

P.O. Box 999

Richland, WA 99352

1-888-375-PNNL (7665)

www.pnl.gov 